* .Pós-doutorado em Ciências Humanas, Doutorado em Ciências Sociais e em Educação, Mestrado em Direito e em Educação. Graduação em Direito e em Ciências Sociais. Professor Associado da UFSCAR. Advogado.e-mail: prof.vinicio@ ig.com.br

** Especialista em Direito e Processo do Trabalho e em Administração Pública. Graduado em Direito e em Gestão Pública. Pós-graduando em Direito Constitucional Contemporâneo no IDCC. Procurador Jurídico do Município de BandeirantesPR. Advogado. e-mail: vinicius. scherch@gmail.com

\section{a Carta Política na Sociedade de Controle}

\section{The Political Charter in Society of Control}

\section{Vinício Carrilho Martinez" Vinícius Alves Scherch**}

Como citar: MARTINEZ, Vinício Carrilho. SCHERCH, Vinívius Alves. A carta política na sociedade de controle. Revista do Instituto de Direito Constitucional e Cidadania, Londrina, v. 3, n. 1, p. 135-154, jan/jun. 2018.

https://doi.org/10.48159/revistadoidcc.v3n1.martinez.scherch

Resumo: A Constituição não é uma Lei Maior, porque "uma" lei não é o que há de maior ou superior na história da Humanidade. Mas sim a condição de se fazer humano, se assim nos fazemos por meio da Política. A Carta Política pode estar contida na Constituição, mas é exatamente o que antecede a lei: é a Política que engendra a Luta pelo Direito. Se toda a luta emancipatória por direitos estiver na Constituição, então, afirmativamente como constituição da condição humana, a Carta Política expressará a Política que há na Constituição. Do contrário, a Constituição, como Lei Maior, será reserva de valor político e de mercado dos Grupos Hegemônicos de Poder.

Palavras-chave: Carta Política. Constituição. Sociedade de Controle. Poder Social. Reabilitação da política.

\begin{abstract}
The Constitution is not a Major Law, because "a" law is not the highest or supreme in the history of Humanity. But the condition of becoming human, if we do so through politics. The Political Charter may be contained in the Constitution, but it is exactly what precedes the law: it is the Politics that engenders the Fight for the Right. If the entire emancipatory struggle for rights is in the Constitution, then, affirmatively as the constitution of the human condition, the Political Charter will express the Politics that is in the Constitution. Otherwise, the Constitution, as the Major Law, will be the political and market value reserve of the Hegemonic Power Groups.
\end{abstract}


Keywords: Political Charter. Constitution. Society of Control . Social Power. Political rehabilitation. 


\section{INTRODUÇÃO}

A Constituição, para que assim seja, precisa conter no mínimo a organização do Estado e os direitos fundamentais, porque, essencialmente, são as normas materialmente constitucionais que carrega. A previsão de organização do Estado e dos direitos fundamentais é o que permite a limitação do exercício do poder e o direcionamento das suas ações para a realização dos objetivos constitucionalmente traçados.

A Carta Política, mais do que isso, é um tratado capaz de organizar a vida em sociedade, tendo por base a existência humana em seus aspectos biológicos, intelectuais, culturais, filosóficos e morais, permitindo ao indivíduo o desenvolvimento pleno de suas potencialidades. Mais do que isso, é nela - Carta Política - que se encontra a reserva de poder social, o zoonpolitikon de Aristóteles $^{1}$ e a possibilidade da razão do próprio Estado existir.

Haberle $^{2}$ aponta os três elementos consagrados de formação do Estado - povo, território, soberania - e consagradores do próprio conceito ideal de Estado de Direito (legalidade), desde Jellinek $^{3}$, Malberg ${ }^{4}$ e Radbruch ${ }^{5}$, para em seguida destacar um quarto elemento na constituição do Estado Constitucional: a cultura.

Cabe destacar que a doutrina alemã, no século XIX, quando pensou o Rechstaat não o fez como um Estado de Direito, mas idealizou um Estado racional de Direito em que o governo pudesse fluir com base na vontade geral e propulsando-se na busca do melhor para todos os indivíduos, e idealizou isso em nítida oposição ao Obrigkeitsstaat, que é o Estado Iluminista, cujo poder era centrado no monarca e no domínio eclesiástico para a busca do bem estar.

Neste plano, objetiva-se especificar que a Carta Política-como constructo da racionalidade política $^{6}$ e jurídica - constitui-se como pilar dos princípios que orientam o ideário ocidental da Política, do direito e, portanto, acerca do Estado.Porém, há que se destacar, desde logo, que a história da constitucionalização da Política (e do Poder Político) orientou-se pela isonomia e equidade e que, assim, sobretudo no século XX, teve o Princípio Democrático ${ }^{8}$ como sustentação do Estado Constitucional.

Predominantemente, foi utilizada a metodologia da abordagem indutiva - partindo da análise de questões particulares para as conclusões gerais - e como técnica de pesquisa foi utilizada a revisão bibliográfica e a coleta de dados em jornais e sítios eletrônicos sobre o tema desenvolvido nas linhas a seguir.

Portanto, por óbvio, só há que se falar do Estado Constitucional sob o Império da Lei Constitucional - que seria agregada de democracia no pós-Segunda Grande Guerra. Enfim: Império da Lei Constitucional Democrática - na esteira também da Declaração Universal dos

\footnotetext{
1 ARISTÓTELES, 2001.

2 HABERLE, 2003.

3 JELLINEK, 2000.

4 MALBERG, 2001.

5 RADBRUCH, 1999.

6 ARENDT, 1991.

7 WEBER, 1979.

8 CANOTILHO, 1999.
} 
Direitos Humanos, de 1948, e da Constituição de Bonn, na Alemanha de $1949^{9}$.

Este movimento de controle social externo do Poder Político - a soberania popular e o Direito Internacional como mecanismos de freios e contrapesos - viria a ser a guarida da atualização da Carta Política no século XXI. Ou não: caso em que somos confrontados pelo Estado de Exceção, bonapartismo legalizado e cesarismo em razão do realismo político.

\section{NÃO HÁ EXCEÇÃO AO DIREITO, NA CARTA POLÍTICA}

Das diversas situações de exceção, uma das mais emblemáticas foi a do nazismo, quando Hitler assumiu o poder e utilizando-se de um decreto, suspendeu as liberdades individuais previstas na Constituição de Weimar. É desta tática de governar com medidas provisórias, que embusteia relevância e urgência, que vem a ideia de que a Carta Política não admite exceção ao direito ${ }^{10}$. Para Agambem ${ }^{11}$ :

O totalitarismo moderno pode ser definido, nesse sentido, como a instauração, por meio do estado de exceção, de uma guerra civil legal que permite a eliminação física não só dos adversários políticos, mas também de categorias inteiras de cidadãos que, por qualquer razão, pareçam não integráveis ao sistema político. Desde então, a criação voluntária de um estado de emergência permanente (ainda que, eventualmente, não declarado no sentido técnico) tornou-se uma das práticas essenciais dos Estados contemporâneos, inclusive dos chamados democráticos.

Uma exceção, protetiva da democracia contra o arbítrio e a ditadura, converte-se em foro privilegiado para falsários: o que era bom virou-se ao Mal ${ }^{12}$. Pois: "embora a Constituição não possa, por si só, realizar nada, ela pode impor tarefas"13.

Desde já se identifica o objetivo primaz da Constituição que antes de ser escrita, ainda na latência do Poder Constituinte, no seu protocolo de intenções, quando ainda está nas mãos do povo, é a busca pela justiça, pela alteridade e pela existência plural. Daí se entender que o epílogo é o Estado de Direito. Ocorre que, no meio do caminho, na fase mais importante do que positivar, ou seja, do que prever direitos, é que os objetivos se perdem, as tarefas não se concretizam e as promessas não se cumprem. Ao revés, entra em cena o Estado de não direito "em que existem leis arbitrárias, cruéis e desumanas que fazem da força ou do exercício abusivo do poder o direito, deixando sem qualquer defesa jurídica eficaz o indivíduo, os cidadãos, os povos e as minorias"14.

Ainda sobre a ideia de Canotilho, o que se impõe é a radical injustiça e a desigualdade na aplicação do direito. De forma sutil, aquilo que serviria de esteio é utilizado para repelir a boa prática e a inclusão. E passamos ao lado negativo do Estado que "pode representar a salvaguarda dos valores mais caros, mas, ao reverso, pode-se constituir no carrasco que suprime ideias, sonhos 9 Lei Fundamental da República Federal da Alemanha. Tradução publicada pelo Departamento da Imprensa e Informação do Governo da República Federal da Alemanha, 1975.

10http://www1.folha.uol.com.br/poder/2017/10/1925971-maia-enfrenta-planalto-e-diz-que-nao-aceita-mais-mps. shtml

11 AGAMBEM, 2004, p. 13.

$12 \mathrm{http}: / /$ congressoemfoco.uol.com.br/noticias/fim-do-foro-privilegiado-e-urgente-diz-fachin/

13 HESSE, 1991, p. 23.

14 CANOTILHO, 1999, p. 4. 
e promove genocídios" ${ }^{15}$.

No caso específico, em vigência a lógica de que "o homem é o lobo do homem"16, invoca-se o direito penal do inimigo ${ }^{17}$ : quer seja o inimigo social, quer seja o denominado inimigo combatente $^{18}$. Na verdade, os dois confluem num só tipo social/penal, ao alcance da mesma prescrição legal. No início era o Estado Penal em estado puro - digamos assim:

Primeiro começam a se legalizar as os privilégios das classes dirigentes e da nova burguesia e a justiça - entendida não só como a jurisdição - passa a ter dois pesos e duas medidas com base no bem comum dos indivíduos. ${ }^{19}$

Em seguida, o mesmo meio avança em constitucionalidade (crimes hediondos como forma de criminalização das relações sociais) e toma corpo no interior do Estado, em suas estruturas e sistemas. Assim, não só o sistema penal é aderente ao controle social como empresta funções tipicamente de exceção para que haja encarceramento político ou seletivo.Na modalidade democrática de exceção, o criminoso político é uma ameaça equiparada ao terrorismo ou ao crime organizado pelo tráfico internacional.

A negação do direito começa a identificar os inimigos nas camadas mais afastadas de qualquer tipo de poder, seja político, econômico, cultural e com isso a crueldade e a desumanidade vão se institucionalizando por meio de leis arbitrárias. Geralmente as doses são pequenas, porém eficazes, tais como cortes em verbas para universidades, diminuição das cotas - barrando a entrada de pobres e negros no ensino público -, políticas de desoneração de empresas que exploram o meio ambiente de forma voraz e, de repente, a prisão perpétua já é uma realidade e as penas mais degradantes que se possa imaginar já estão institucionalizadas e legalizadas.

A exceção, evidente, está em se manter alguém preso por portar um frasco de detergente, em ato de desagravo ao establishment político $^{20}$, ou de se aplicar a pena de total dessocialização política $^{21}$ : com a proibição de que venha a participar de qualquer evento de natureza política. Em tal quadro, um ato pode sofrer sansão criminal com penas desumanas, desde que praticado por adversários políticos, mas se este mesmo ato é cometido por um correligionário, ou um amigo, ou pela polícia contra os inimigos 22 é encoberto ou glorificado pela mídia e pela sociedade.

O homem não é mais um animal político e a condição humana exclui os que não se incluem docilmente no sistema produtivo: "estrita proibição de frequentar manifestações ou

15 FACHIN e SAMPAR, 2017, p. 1.

16 HOBBES, 1983

17 JAKOBS, 2005.

18 "Oír al enemigo, es cosa cierta / que siempreaprovechó más que dañase" (Cervantes, 1999, p. 47).

19http://www1.folha.uol.com.br/poder/2017/08/1906618-temer-obtem-votos-para-barrar-denuncia-de-corrupcao-nacamara.shtml

20http://noticias.uol.com.br/cotidiano/ultimas-noticias/2017/09/15/doente-rafael-braga-deixa-a-penitenciaria-debangu-para-cumprir-prisao-domiciliar-no-rio.htm.

21 Arendt (1991, p. 15) explica que: “Com a expressão vitaactiva, pretendo designar três atividades humanas fundamentais: labor, trabalho e ação [...] A ação, única atividade que se exerce diretamente entre os homens sem a mediação das coisas ou da matéria, corresponde à condição humana da pluralidade, ao fato de que homens, e não o Homem, vivem na Terra e habitam o mundo. Todos os aspectos da condição humana têm alguma relação com a política; mas esta pluralidade é especialmente a condição - não apenas a conditio sinequa non, mas a conditio per quam - de toda vida política. Assim, o idioma dos romanos - talvez o povo mais político que conhecemos empregava como sinônimas as expressões $<$ viver $>$ e $<$ estar entre os homens $>$ (inter homines esse), ou $<$ morrer $>$ e $<$ deixar de estar entre os homens> (inter homines esse desinere)". [grifos nossos]

22 Inimigos podem ser adversários políticos, pobres, negros, mulheres, minorias, idealistas pela democracia e defensores dos direitos humanos. 
protestos, e para garantia da ordem pública, decreto a prisão preventiva dos acusados"( $\operatorname{sic})^{23}$. Note-se que as duas ações são realizadas em total acréscimo de legalidade referendada pelos juízos de primeira instância e chanceladas pelos tribunais superiores.

Não há ilegalidade se amparada em interpretação recessiva da Constituição - Cesarismo Regressivo ${ }^{24}$. A própria legitimidade se constrói socialmente sob o argumento de que "não se pode depredar o patrimônio público" e, se assim agem, devem responder pela integralidade da pena. Pena que, reprise-se, implica na total exclusão do espaço público, com a condenação de não insistir na socialização como "animal político".

A pena assim imposta não se refere à limitação da liberdade (prisão), mas, muito mais grave, à perda do sinal ontológico da humanização: a pena incorre na perda da qualidade política de igualdade frente aos demais "animais políticos".

\section{SEM ISONOMIA E EQUIDADE NÃO HÁ SOCIABILIDADE POLÍTICA}

Para muitos não haveria diferença significativa entre isonomia e igualdade. Porém, assinalando-se uma sutileza, que se torna material, podemos nos encontrar com a história, mas basta observarmos, a título de exemplo, que desde as Capitanias Hereditárias - o nome "hereditário" já caracteriza bem isso - instituiu-se no Brasil o coronelismo, o paternalismo e as grandes propriedades latifundiárias improdutivas, que até agora permanecem vivos e presentes. Vejamos esquematicamente:

1. Igualdade: todos são iguais perante a lei.

Todavia, machismo e racismo já haviam criado desigualdades antes da lei e permanecem não só como um constructo, mas como práxis que nem por força de leis, como a Lei Maria da Penha, por exemplo, é erradicada da convivência humana. A zona obscura da violência racial e de gênero ocupa uma magnitude oficialmente desconhecida e convencionalmente assim se permanece para dar azo ao argumento de que o Brasil diminuem, estatisticamente, tais práticas.

2. Isonomia: diante da desigualdade instalada a lei diz que " não haverá discriminação de sexo, cor, idade, credo". Lembrando que não há raça eque o termo aparece no art. $3^{\circ}$, IV da Constituição, com a promoção do bem de todos enquanto um objetivo fundamental da República Federativa do Brasil. A questão racial não pode começar e nem terminar num crime inafiançável e imprescritível, sem que se construam condições de combate à prática e que se promova uma ampla inclusão, além da ideologia, materializando o acesso homogêneo aos direitos e aos bens disponíveis aos indivíduos.

3. Equidade: diante da desigualdade instalada e das discriminações existentes, a lei autoriza tratamento desigual para desiguais. Estatuto do idoso por exemplo.

O Estado de Direito pensou a igualdade na relação entre poderes. Por isso votavam nobres e ricos, mas mulheres e analfabetos não. De certo modo a isonomia especifica a igualdade, como 23 https://stj.jusbrasil.com.br/jurisprudencia/158992613/habeas-corpus-hc-312034-rj-2014-0334760-7. 24 (Gramsci, 2000). 
espécie no primeiro e gênero no segundo ${ }^{25}$.É o gênero que sofre da desigualdade. São homens e mulheres que vivem concretamente a desigualdade e a falta de leis e ações corretivas.Por isso, a equidade ataca a desigualdade real. Ainda que seja definida em lei, discrímen, a equidade só existe em eficácia como política pública. A igualdade foi criada por e para homens adultos, brancos e ricos. Por isso são os mesmos que assopram a ideologia de meritocracia.

A isonomia acrescentou as mulheres, os pobres e o Estado Laico. A constituição reconheceu isso. Mas, não é suficiente pensar que este é o ápice, melhor dizendo, a Constituição não é um ponto de chegada, ao revés, é o ponto de partida, tanto que verbaliza-se diversas vezes em frases imperativas, no infinitivo pessoal, como no exemplo de intentar "construir uma sociedade livre, justa e solidária" - e vem com inúmeras normas programáticas. A Constituição é o projeto, o plano piloto para o qual se aponta a direção para erigir o Estado de Direito, não se descumpre-a contrariando suas disposições somente, visto que também é descumprida quando the é negada a ação construtiva, quando são deixados de lado os seus valores.

Desse modo, a equidade não aconteceu. Também por isso igualdade formal sem políticas públicas vale apenas na relação entre poderes, mas não na distribuição dos poderes. Tanto quanto a meritocracia sem equidade é a desigualdade concreta. No Reino da desigualdade, a meritocracia anula o próprio princípio da igualdade. Em exemplo simples, é como cobrar de uma criança a eficiência esperada de um profissional com 30 anos de mercado.

E é óbvio que são diferentes e desiguais. Do mesmo modo que homens brancos e ricos, e mulheres pobres e negras. A isonomia foi um degrau na igualdade plantada pelos burgos, diante do seu rei. Tanto quanto a isonomia foi uma conquista das mulheres, frente aos maridos brancos e alfabetizados. Os pobres ainda estão à espera da equidade.

Os ideais de liberdade e de emancipação demoraram - e demoram muito - para amadurecer ao longo do que descreve a história da humanidade e a violência com que são combatidas demonstram que não são acessíveis a todos, afinal "a independência é o privilégio dos fortes, da reduzida minoria que tem o calor de autoafirmar-se"26.Por volta de 1548, La Boétie ${ }^{27}$ escreveu que todo ser que é dotado de sentimento se sente mal com a sujeição e busca a liberdade, de modo que:

(...)se os bichos, até os criados para o serviço do homem, só podem se submeter depois de protestarem um desejo contrário - que vício infeliz pode então desnaturar tanto o homem, o único que realmente nasceu para viver livre, a ponto de fazê-lo perder a lembrança de sua primeira condição e o próprio desejo de retomá-la?”

Sobretudo a liberdade e a igualdade, enquanto sinônimo de hegemonia para as classes dominantes, é o que desperta a vontade de alcançar também este status naqueles que são constrangidos e ao mesmo tempo servem de base para a sustentação da condição benéfica daqueles. A liberdade, a igualdade e a solidariedade, enquanto bandeira de uma revolução somente foram conquistadas mediante violência, daí se concordar com Nietzsche na parte em que credita à violência as conquistas históricas no âmbito político e social.

$25 \mathrm{Na}$ clássica lição histórica: "tratar os iguais, igualmente (isonomia); os desiguais, desigualmente (equidade)".

26 NIETZSCHE, 2001, p. 42.

$27 \quad$ LA BOÉTIE, 1999, p. 82. 
A liberdade e a igualdade são conceitos do Iluminismo. Mas a síntese da solidariedade não se efetivou e ao que tende a crer, não se efetivará ${ }^{28}$. Assim como a equidade está na lei, e é descumprida todos os dias. A igualdade foi criada na Política de Aristóteles ${ }^{29}$ (A equidade também).

A isonomia nasceu na Declaração Universal dos Direitos das Mulheres, em 1789. A igualdade foi criada na Polis do homem branco.A isonomia pertence aOikós, à casa, ao universo feminino. A igualdade da Polis só chegou aos burgos em 1215, na Carta Magna ${ }^{30}$ - seguida de intensa guerra civil. Isto gerou a necessidade do Estado Moderno ${ }^{31}$. Mas foi preciso haver a Revolução Francesa para que houvesse uma "mesma lei" (iso + nomia) para todos os homens livres. Daí o rei ser guilhotinado.

Nos EUA, a liberdade implicou em revolução de independência, e depois na igualdade que não chegava aos negros. O que só avançou na década de 1960, com leis de isonomia (mesmo banheiro para brancos e negros) e ações afirmativas, discrímen, formando uma classe média não branca: de negros. Dentro deste quadro, destaca-se a desobediência civil de Martin Luther King, ao liderar o movimento negro de resistência às leis que não lhes concediam direito de cidadania.

Por meio de manifestações pacíficas, as autoridades cederam à minoria (cerca de um décimo da população) os direitos civis e políticos que reivindicavam. Do legado escrito por King, são retiradas importantes lições: (i) minorias, por ação de massa, são ideais para se implementar resistências localizadas; (ii) a não violência e a sujeição às sanções é uma boa conduta para aceitação na opinião pública; e (iii) a justificativa para a desobediência voltou a ter um conteúdo moral e não somente político ${ }^{32}$. Porém, Martin Luther King foi assassinado em 4 de abril de 1968, já que era odiado e visivelmente um inimigo de Estado (ao menos do status quo).

Historicamente, as mulheres fizeram seu documento legala partir de 1789. Mas, ainda sem força política, tiveram que queimar os sutiãs na Polis do século XX. Antes disso foram queimadas dentro de fábricas, porque faziam greve para poder amamentar os filhos pobres.

Por isso, o Dia Internacional da Mulher é um marco da isonomia, tanto quanto o regime de cotas para negros nas universidades dos EUA é um emblema da equidade. Interessante frisar que nos matamos em debates ilógicos (meritocracia) que franceses e estadunidenses liquidaram há, no mínimo, 50 anos.

O Maio de 1968, com os debates de Sartre e Camus sobre a descolonização e a isonomia, aqui nem começaram. Na prática, o debate é estéril porque o jurista desconhece a história - e não quer conhecer, porque é mais fácil decorar a lei do que interpretar a vida. Com efeito, a existência real do Estado de Direito faria uma revolução no Brasil.

A história indica que existiram épocas em que, diante de regimes totalitários e autoritários, o domínio dos bens e do conhecimento se restringiu a determinados grupos, cabendo citar a igreja, os militares e até as universidades, por motivos dos mais diversos, ora para preservar o poder, 28 http://m.folha.uol.com.br/poder/2017/10/1924781-tendencia-para-o-autoritarismo-e-altano-brasil-diz-estudo.shtml

29 ARISTÓTELES, 2001.

30 MIRANDA, 1990

31 HOBBES, 1993

32 COSTA, 2012, p. 687. 
ora para evitar o acesso e ahorizontalização das ideias. Esse movimento de exclusão, que busca expelir para fora os indivíduos que não se amoldam nas estruturas planejadas e perfectibilizadas pelo Estado - através dos governantes -, é a chave que perpetua a desigualdade e torna inviável a concretização da equidade e da isonomia. O desafio que se assenta é o de não abnegar as conquistas sociais, ou seja, reconhecer a historicidade dos direitos fundamentais e só assim abdicar o Estado de não direito, retomando a razão crítica e o Poder Popular.

Ao não dar importância aos fatos históricos e contribuir para a mecanização do direito, a sociedade vai se tornando retrógrada e permitindo que se perpetuem a desconstrução da equidade e da isonomia, afastando-se, portanto, da Carta Política, pois "somente se compreendemos esta essencial função histórica das declarações dos direitos, é possível também entender seu desenvolvimento e suas metamorfoses no nosso século"33.

Assim a Carta Política não é entregue aos indivíduos, mas é feita por eles, de modo que implica a participação popular ampla e irrestrita. A Carta política não pode ser abandonada nas mãos dos Três Poderes, ela precisa, assim como o Estado, de um fio condutor, de uma mão realizadora e essa tarefa não pode ser monopolizada, mas deve ser estendida a todos. Canotilho ${ }^{34}$ afirma:

A constitucionalização dos direitos revela a fundamentalidade dos direitos e reafirma sua positividade no sentido de os direitos serem posições juridicamente garantidas e não meras proclamações filosóficas, servindo ainda para legitimar a própria ordem constitucional como ordem de liberdade e de justiça. Uma outra dimensão deve, porém, ser revelada: não basta a consagração de direitos numa qualquer constituição. A História demonstra que muitas constituições ricas na escritura de direitos eram pobres na garantia dos mesmos. As constituições de fachada, as constituições simbólicas, as constituições álibi, as constituições semânticas, gastam muitas palavras na afirmação de direitos mas pouco podem fazer quanto à sai efectiva garantia se os princípios da própria ordem constitucional não forem os de um verdadeiro Estado de direito.

Os arremedos de formas de Poder Popular construídos lentamente parecem fenecer à luz do sol. O poder que se concentra longe do povo cada vez é menos social.

\section{PODER SOCIAL}

Poder não é algo de fácil definição, por ser multifacetado, pluridimensional, envolver diversos agentes e interesses muito diferentes e por vezes antagônicos, contraditórios. Entretanto, pode-se dizer que o poder sempre se expressa como relação.

Por si, a expressão Poder Social já indica que o poder pertence ao grupo social, que é compartilhado pela sociedade; provém de uma forma tradicional de poder nas sociedades primitivas, tal como analisado pelo antropólogo Pierre Clastres ${ }^{35}$.

\begin{tabular}{ll}
\hline 33 & AGAMBEN, 2007, p. 135. \\
34 & 1999, p. $19-20$ \\
35 & 1990.
\end{tabular}


Em sentido semelhante, ao retomar a Polis, a vita ativa e depois o ideal republicano clássico, Hannah Arendt $^{36}$ - uma filósofa e escritora judia e alemã, perseguida pelos nazistas e exilada nos EUA - nos diz que a política e o poder precisam se alimentar de urbanidade, civilidade, convivialidade, sociabilidade: "Pois a polis era para os gregos, como a res publica para os romanos, em primeiro lugar a garantia contra a futilidade da vida individual, o espaço protegido contra essa futilidade e reservado à relativa permanência, senão à imortalidade, dos mortais" ${ }^{\prime 37}$.

O poder, nesta linha de argumentação, sempre é social, organizador, orgânico, é um amálgama, uma argamassa, um liame que produz solidariedade. Aliás, é a própria teia que enreda a vida social e com isso evita que as discórdias degenerem ou degradem os níveis mínimos de sociabilidade e de solidariedade; é uma reserva contra a absoluta violência de "todos contra todos" (na mais célebre fórmula de Hobbes).

Hannah Arendt ${ }^{38}$, em total desacordo com o senso comum, denuncia a violência que se estampa nas ações desmotivadas ou descontroladas pelo poder político-institucional (leia-se Estado), isto é, quando o que outrora fora um poder social forte, criador e organizador de elos sociais, acabou por se revelar instável, corrupto ou fraco.

Em sentido contrário, a violência de "um contra todos" é em si um claro sinal de crise individual (em atitude criminosa, por exemplo, age-se contra o "todo social"), bem como indica a crise institucional (corrupção generalizada no interior do Estado) ou social, como ocorre na guerra civil ou na insurreição que desafia abertamente (de modo articulado ou não) o Estado — na medida em que o poder político-institucional já se mostre inoperante.

Desse modo, entendamos aqui o Estado como a agência reguladora do próprio "poder institucional" e a sociedade como a mola propulsora do poder social. Portanto, o poder, desde a origem, é ou deveria ser social, mas pode se corromper. A violência, ao contrário do poder social ${ }^{39}$, via de regra é ilegítima, funcionando como uma ação descaracterizada, desconectada do social; está próxima da imposição de "uma vontade a outrem" (como no pensamento do sociólogo Max Weber). A análise é tornada clássica pela Filosofia Política de Hannah Arendt ${ }^{40}$ :

Poder, vigor, força, autoridade, violência seriam simples palavras para indicar os meios em função dos quais o homem domina o homem; são tomados por sinônimos porque têm a mesma função [...] O poder nunca é propriedade de um indivíduo; pertence a um grupo e permanece em existência apenas na medida em que o grupo permanece unido. Quando dizemos que alguém está no poder, na realidade nos referimos ao fato de que ele foi empossado por um certo número de pessoas para agir em seu nome [...] (potestas in populo, sem o povo ou grupo não há poder) [strenght] $\mathrm{O}$ vigor inequivocamente designa algo no singular, uma entidade individual [...] é da natureza de um grupo e de seu poder voltar-se contra a independência, a propriedade do vigor individual [...] A força (force) [...] às "forças da natureza" ou à "força das circunstâncias" [...] (la force deschoses) deveria indicar a energia liberada por movimentos físicos ou sociais.

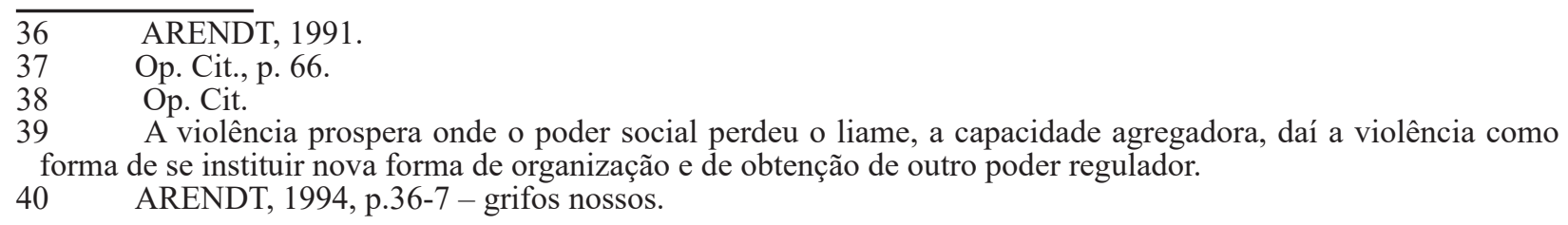


A autoridade [...] pode ser investida em pessoas [...] Senado romano (auctoritas in Senatus) [...] Sua insígnia é o reconhecimento inquestionável por aquele a quem se pede que obedeçam; nem a coerção nem a persuasão são necessárias [...] Conservar a autoridade requer respeito pela pessoa ou pelo cargo. $O$ maior inimigo da autoridade é, portanto, o desprezo, e o mais seguro meio para miná-la é a risada [violência] Fenomenologicamente, ela está próxima do vigor, posto que os implementos da violência, como todas as outras ferramentas, são planejados e usados com o propósito de multiplicar o vigor natural até que, em seu último estágio de desenvolvimento, possam substituí-lo.

O Poder Social é definido como a capacidade de organizar relações sociais, a fim de agir em relativa harmonia. Ainda se diz que se constitui na capacidade de acessar recursos humanos e/ou materiais para obter e controlar os resultados almejados. Enfim, pode-se dizer que o Poder é social porque pertence a um grupo. Contudo, deve-se indagar se o Poder Social sempre será uma atividade racional. De modo simples, o Poder Social reflete a capacidade humana para se propor formas de organização social. Assim, poder social é uma capacidade humana:

- Constitutiva da fabricação de resultados que afetem outros;

- Sistêmica: capaz de realizar objetivos coletivamente vinculatórios;

- Organizacional ou disciplinar: modelando desejos, ações, discursos e a própria subjetividade;

- Racional e voltada à dominação, em busca de determinados resultados.

Em suma, para Arendt: "A forma extrema de poder é o Todos contra Um, a forma extrema da violência é o Um contra Todos" ${ }^{\text {"41 }}$. Lembrando-se que este Um tanto pode ser um príncipe, um déspota quanto o Estado na forma totalitária. No sentido global do poder, quando há um revés nesta lógica do Eu-controlo-o-poder, ultrapassando-se a luta por sobrevivência, mas com reconhecimento da intersubjetividade ${ }^{42}$ ou simples práxis social, então, é porque já não estão em vigor a impotência, a violência e a corrupção (o exato contrário, o sentido oposto da política, para Arendt).

Destaca-se que o "acordo genuíno" que constituiu o poder social não poderia se converter em coerção pelo sistema, desconectando-se das resolutivas sociais, uma vez que esta mutação simplesmente converteria poder em violência. Afinal, o poder do consenso/legítimo repousa na persuasão: "imposição singularmente não-impositiva ${ }^{43}$ ". Porque é um “poder proposto", interposto, não-imposto. Ainda é preciso lembrar que Habermas considera que o significado de poder em Arendt origina-se da vitaactiva, na sua práxis social - em outros termos, na "capacidade de se alcançar um acordo visando a ação conjunta que transforma".

É necessário retomar algumas diferenciações, neste caso entre Arendt e Weber, pois o "poder como consenso" não se avalia pelo êxito dos atores, mas sim pela "aspiração comum à validade razoável". Para Habermas, o poder em Arendt é fonte da legitimidade validada pela práxis

$41 \quad$ ARENDT, 1994, pp. 35-6 - grifos nossos.

42 HONNETH, 2003.

43 Aqui o cuidado exigido seria o de não confundir "persuasão" com massificação e é isto o que Honneth (2003) chama claramente de "reconhecimento intersubjetivo", sem imposição heterônoma e sem manipulação coletiva das vontades individuais. Persuasão como "validação legítima". 
social e figura, portanto, como fruto de um consenso almejado/alcançado na própria comunicação ou comunidade política ${ }^{44}$. Ou, então, como quer definir Hannah Arendt, de modo preciso, a vitaactiva é sinônimo de ação política e esta estreita relação constitui o "cerne humano". O homem é um animal social, de múltiplas relações de convivialidade, conectividade, civilidade, isonomia ${ }^{45}$, isegoria; mas, sem a política, não passaria de um animal social, como aliás a natureza tem vários tipos e espécies. Sem política não há humanidade, apenas indivíduos socialmente determinados; e sendo que a política é exatamente a capacidade humana de modificar as determinações sociais, econômicas, culturais, jurídicas.

Ainda é preciso reforçar que sem liberdade de expressão, não há manifestação pública e todos seriam aneulogou: sem direito e sem voz ativa ${ }^{46}$. Indubitavelmente, o homem é um animal político, aprioristicamente, mas apenas sob a égide da vitaactiva que requer movimento e ação para a transformação individual e social ${ }^{47}$. A dignidade de se envolver com o poder provém dessa voz ativa: a altivez política.

Desse modo, para Arendt, o poder seria efeito da ação comunicativa, mas também se revelaria em três níveis ou modalidades: a) regulamento que sobrevém à práxis; b) resistência à opressão; c) atos revolucionários inaugurais ${ }^{48}$. O poder é práxis, mas a práxis de Arendt vem da polis $^{49}$. Mesmo que limitado, esse conceito de práxis procura exasperadamente pelo reconhecimento de uma "intersubjetividade multifacetada, mas não-mutilada".

O efeito direto dessa práxis no poder seria preservar a luta pelo reconhecimento da própria intersubjetividade no interior do mundo da vida. Mais especialmente, na modernidade, práxis e vitaactivase aproximam do que chamamos de espaço público ou "esfera pública" — quando se encontram, na modernidade e diferentemente da polis grega, o sistema político-institucional com o mundo da vida: aí estaria, sobretudo, a ideia da representação política, parlamentar ou legislativa. A vontade geral se mantém na transferência da capacidade de ação, da práxis, mas somente se não houver mitigação da soberania popular, como mandato vinculado de mando ao poder social, como comando: dominação compartilhada pelo grupo ou pelas regras definidas globalmente, com anuência coletiva.

De todo modo, se o direito obedece à política (enquanto poder social ou instrumental do Estado), não é menos verdade que o direito precisa ser mais concreto do que a moral para, assim, não se diluir na própria arena política originária. Isto, evidentemente, evitaria um ciclo vicioso, opondo-se perigosamente o teleológico ao social, em que as regras apenas mantêm viciosamente o status quo. Aliás, este "mecanismo institucional de monopólio da produção legislativa" somente pode funcionar se o direito for aceito e reconhecido pela maioria como legítimo, isto é, se o direito se tornar verdadeiramente social. Portanto, uma das maiores dificuldades enfrentadas diante da realidade pragmática do direito (inclusive do "direito ao reconhecimento") é, justamente, entender/encarar o direito como parte do poder social e não só como recurso instrumental do poder 44 HABERMAS, 1980, 103.

45 O reconhecimento da igualdade formal é essencial ao "reconhecimento do discrímen".

46 ARENDT, 1998.

47 ARENDT, 1991.

48 HABERMAS, 1980 , p. 103.

49 Op. Cit., 104. 
extroverso/funcional do Estado ${ }^{50}$.

Quanto mais concreto for o caráter socialmente impositivo ${ }^{51}$ do direito, tanto maior a legitimidade e a aceitabilidade das normas fundamentais de sociabilidade e tanto mais autoreguláveis os projetos teleológicos de poder: os fins seriam mais comedidos pelos meios. Justamente porque as vontades ou os valores estariam "controlados" pelo direito socialmente positivado este que é aberto à interpretação, mas já partindo-se de um sentido firmado e não "figurado". Enfim, como se vê, todo o "problema do direito" (mas também seria da arte, da política, da educação) é, primeiro, quanto à legitimidade e, só depois, quanto à validação.

\section{RUPTURA ENTRE HOMEM E POLÍTICA PELA SOCIEDADE DE CONTROLE E REABILITAÇÃO DA CARTA POLÍTICA}

A cultura, enquanto um elemento do Estado Constitucional, constantemente sofre ataques à medida que incentiva a reprodução da razão crítica e reconhece nos elementos históricos e sociais a força progressista dos direitos fundamentais. Tomada como paradigma, a cultura tem inúmeros sentidos podendo significar o conjunto de conhecimento, lei, costumes, arte e identidade de uma sociedade.

Conforme vai se retirando a cultura, seja pela falta de acesso aos bens intelectuais ou pela sua banalização - que é um ato de instrumentalizar a cultura -, a sociedade vai sendo descaracterizada e, com isso, a pluralidade é rigorosamente repudiada e as minorias são extintas.

Não há como pensar a Carta Política desconsiderando ou extinguindo a cultura. Isso porque só se pode pensar em uma Carta Política de forma sistêmica, observando todas as suas disposições, princípios e valores, em todos os seus aspectos: políticos, civis, econômicos, sociais e culturais. Ao fragmentar a percepção da Carta Política, tem-se a abertura para a entrada de regimes fascistas, totalitários e autoritários, que distorcem os direitos fundamentais e procrastinam a concretude da Constituição. Em tal situação é recorrente a deterioração das condições de vida das pessoas, e com a eliminação da cultura as conquistas sociais tornam-se irrelevantes não só do ponto de vista histórico, mas também no plano prático.

De tal modo que a sociedade toma a forma-Estado de uma sociedade de controle ${ }^{52}$, e suas características mais marcantes são: a descaraterização dos direitos, o desencanto da razão com a possibilidade de realização social e a criação de uma massa homogênea que é consumidora de uma indústria cultural portadora da ideologia dominante.Adorno ${ }^{53}$, explica como a indústria cultural se implanta na sociedade e vai retirando a razão dos indivíduos para dar lugar à instrumentalização:

O sistema educativo alemão, inclusive a universidade, os teatros com função de guia no plano artístico, as grandes orquestras e os museus estavam sob proteção.

$50 \quad$ SUNDFELD, 2004.

51 Como consenso obtido pelo reconhecimento e validado pela livre comunicação dos sujeitos envolvidos e requerentes, e não como heteronomia política, jurídica ou moral. Mas aí o problema seria quanto aos costumes, tanto comus quanto ethos, porque são entes culturais relativamente fechados em torno de regras sociais anteriormente definidas e não predispostas a modificações substanciais subrepticiamente.

$52 \quad$ HARDT \& NEGRI, 2005.

53 2002, p. 15-16. 
Os poderes políticos, Estados e comunas, que tinham recebido essas instituições como herança do absolutismo, haviam lhes deixado parte daquela independência das relações de força explícitas no mercado, a qual lhes fora concedida, apesar de tudo, até fins do século XIX, pelos príncipes e senhores feudais [...] Por ela, dignos editores literários e musicais podiam se ocupar de autores que não rendiam muito mais que a estima dos especialistas. Só a obrigação de inserir-se continuamente, sob as mais graves ameaças, como expert estético na vida industrial, sujeitou definitivamente o artista. Há algum tempo eles assinavam suas cartas, como Kant e Hume, com a expressão "seu mais humilde servo", no entanto, minavam as bases do trono e do altar.

Hoje chamam pelo nome oschefes de governo, e são submetidos, em todo impulso artístico, ao juízo dosseus governantes iletrados [...] Sob o monopólio privado da cultura sucede de fato que "a tirania deixa livre o corpo e investe diretamente sobre a alma". Aí, o patrão não diz mais: ou pensas como eu ou morres. Mas diz: és livre para não pensares como eu, a tua vida, os teus bens, tudo te será deixado, mas, a partir deste instante, és um intruso entre nós. Quem não se adapta é massacrado pela impotência econômica que se prolonga na impotência espiritual do isolado. Excluído da indústria, é fácil convence-lo de sua insuficiência. Enquanto agora, na produção material, o mecanismo da demanda e da oferta está em vias de dissolução, na superestrutura ele opera como controle em proveito dos patrões. Os consumidores são os operários e os empregados, fazendeiros e pequenos burgueses. A totalidade das instituições existentes os aprisiona de corpo e alma a ponto de sem resistência sucumbirem diante de tudo o que lhes é oferecido.

Expressão mais legítima do capitalismo, "a indústria cultural continuamente priva seus consumidores do que continuamente lhes promete" ${ }^{54}$, e o indivíduo não tem valor por existir, mas por ser útil. Com isto, a indústria cultural estabelece-se por meio de uma técnica - mas não só por ela - de produção em série e de homogeneização.Essa forma de proceder é suficientemente eficaz para retirar a individualidade e o aspecto artístico e humano das obras intelectuais e da sociedade. Esta técnica de reprodução em massa, utilizada pelos detentores do poder econômico exerce grande influência sobre a sociedade, chega ao ponto da racionalidade técnica se identificar com a racionalidade de domínio (dominiun: propriedade; dominus: senhor). A indústria cultural retira a consciência das massas e instaura o poder de mecanização sobre os indivíduos, vendendo imagens de bens de consumo ideais.

Da mesma forma que a indústria cultural tem um desdobramento mercadológico, é utilizada como tática de manipulação na política, incutindo falsas verdades que são consumidas pelos indivíduos como se houvesse um candidato messiânico e capaz de resolver todos os problemas nacionais a partir do retorno ao conservadorismo e ao militarismo. Contrariando todo o já exposto a respeito do Poder Social, a indústria cultural é responsável por maquiar a cultura e pôr à disposição das pessoas a ideia de que precisam de um salvador e que são incapazes de resolver os impasses do Brasil;como revogação tácita de que "todo o poder emana do povo", uma constante da Constituição que deveria inibir a sociedade de controle.

Na sociedade de controle, já não é necessário mais vigiar as pessoas, elas são conduzidas 
para onde o dominador - que detém o poder e o domínio sobre o medo - apontaBauman ${ }^{55}$. Desprovidos de uma razão crítica e da capacidade de questionar, submetidos à falsa racionalidade, os indivíduos consomem a ideologia dominante e opositores são caraterizados como inimigos, restando somente duas escolhas: aderir à sociedade de controle ou serem esmagados por ela.

A sociedade de controle aproveita-se do conformismo - característico da hegemonia capitalista em que o homo laboransvence o homo fabere o homo politikos - e passa a ditar as regras da sociedade sobrepondo a existência do ser acima de seu significado e da ação política. Daí vem a ruptura da Política (condicionada pela hominização) com a sociedade de controle, a ausência da razão pela necessidade de manter-se vivo é o que justifica a submissão aos regimes totalitários com o aspecto de bem comum: a essência de exceptio ${ }^{56}$.

Através dessa estrutura política ${ }^{57}$, a vida é garantida - nos limites do querer dos governantes - e o sistema totalitário é implantado de modo a não permitir escolhas; conformados com um hedonismo de massa, os indivíduos são guiados pela vontade geral criada na produção fabril da vontade de consumir. Em essência, o papel do governante é somente plantar a ideia e não precisa mais se esforçar, pois a sociedade de controle se faz no meio da população, foi assim com o nazismo e ainda ocorre nos dias atuais, com as repercussões no direito penal seletivo, no criminoso político, na sede de justiça da Operação Lava-Jato e na resistência em incluir minorias.

$\mathrm{Na}$ sociedade de controle as pessoas tornam-se despolitizadas e são despolitizadas pelo próprio Estado, reduzindo as discussões e os diálogos tão somente aos aspectos da vida nua, ou seja, discutir aspectos fisiológicos da vida tais como saúde e alimentação e retirar da pauta as questões políticas. A sociedade cada vez mais se converte em "uma organização normal e coletiva (e, portanto, política) da vida humana baseada unicamente sobre a vida nua" 58 , que nada mais é do que um campo de concentração moderno, autogerido e sem a violência - física e moral - aparente, por isso sociedade de controle.

Assim como na indústria cultural a razão crítica é afastada, também o é na sociedade de controle. É um ponto de ligação de uma de outra, que se completam no objetivo de sobrepor a razão instrumental e dominar a sociedade com a ruptura do ser humano com a política.

É necessário, portanto, reconciliar os indivíduos com sua razão crítica, melhor

\footnotetext{
$55 \quad$ BAUMAN, 2013.

56 Quando o estado de exceção torna-se regra e o tempo de guerra é interminável, a tradicional distinção entre guerra e política fica cada vez mais obscura [...] Nessas guerras, é cada vez menor a diferença entre o exterior e o interior, entre os conflitos externos e a segurança interna [...] Uma das consequências desse novo tipo de guerra é que os limites da guerra tornam-se indeterminados, em termos espaciais e temporais [...] Uma guerra para criar ou manter a ordem social não pode ter fim (HARDT \& NEGRI, 2005, p. 33-35).

57 "Por muito tempo, um dos privilégios característicos do poder soberano fora o direito de vida e de morte. Sem dúvida, ele derivava formalmente da velha pátria potestasque concedia ao pai de família o direito romano de 'dispor' da vida de seus filhos e de seus escravos; podia retirar-lhes a vida, já que a tinha 'dado' [...] O poder era antes de tudo, nesse tipo de sociedade, direito de apreensão das coisas, do tempo, dos corpos e, finalmente, da vida; culminava com o privilégio de se apoderar da vida para suprimi-la [...] Poderia ter tomado, em outro nível, o exemplo da pena de morte. Por muito tempo, ela foi, juntamente com a guerra, a outra forma do direito de gládio; constituía a resposta do soberano a quem atacava sua vontade, sua lei, sua pessoa [...] Pode-se dizer que o velho direito de causar a morte ou deixar viver foi substituído por um poder de causar a vida ou devolver à morte [...] A velha potência da morte em que se simbolizava o poder soberano é agora, cuidadosamente, recoberta pela administração dos corpos e pela gestão cuidadosa da vida [...] $\mathrm{O}$ homem, durante milênios, permaneceu o que era para Aristóteles: um animal vivo e, além disso, capaz de existência política; o homem moderno é um animal, em cuja política, sua vida de ser vivo está em questão" (FOUCAULT, 1988, p. 127-134 - grifamos). AGAMBEN, 2007, p. 142.
} 
dizendo,verter o homem no animal político, uma vez que ainda que seja retirada a cultura da humanidade, ela permanece como inerente à condição humana. O ser humano é um animal cultural e político por excelência e não pode ser reduzido à natureza somente, na condição da vida nua que Agamben retrata.

A reconstrução da Carta Política vem no sentido jurídico não limitado de validade da Constituição ou de promover uma nova constituinte, mas no sentido de viabilizar um elo comunicativo entre o direito e a sociedade, entre o governante e as pessoas, entre o indivíduo e o Estado, para que se possa extrair legitimidade das decisões que afetam individual e coletivamente a vida das pessoas.

A partir disto, é possível reconstruir a Carta Política a partir da razão prática, que como Habermas ${ }^{59}$ explica, dá-se no aspecto da interação entre os seres humanos, que figura em um dos princípios racionais, juntamente aposta à racionalidade comunicativa.

Para Habermas ${ }^{60}$ a comunicação racional é aquela construída com base na verdade e na honestidade, ou seja, na possibilidade de os indivíduos estabelecerem diálogos sem serem movidos por paixões ou predileções, conduzindo a objetivos interpessoais, de modo que os atores deixam de priorizar o individual e privilegiam o que têm em comum, vinculando vontades e preferências. Trata-se de um consenso racional e não um consenso instrumental como o da sociedade de controle. Aqui a vida é contemplada em sua inteireza e não meramente em sua faceta fisiológica.

Habermas estabelece a ideia de que há componentes estruturais do mundo da vida, elencando a cultura, a sociedade e a personalidade;para a manutenção desses componentes são utilizados processos de reprodução. Tudo é analisado, basicamente, a partir do agir comunicativo, de modo que aparecem como processos a reprodução cultural, a integração cultural e a socialização. O ápice dessa interação entre componentes e processos de reprodução se dá com esquemas de interpretação passíveis de consenso (saber válido), relações interpessoais reguladas legitimamente e capacidades de interação (identidade pessoal), para que se alcance o conceito de mundo da vida. Assim, o mundo da vida pode ser entendido como uma relação dos atos comunicativos entre os indivíduos, onde é possível a interação de mundos internos (subjetivos), fazendo-se compartilhar a cultura por meio da linguagem comum que é obtida com a comunicação, resultado disso o surgimento do mundo objetivo e de um mundo social que é a somatória dos mundos internos ${ }^{61}$.

A Carta Política é expressão de um interagir plural, que leva em conta todas as qualidades e ideias dos indivíduos, por isso a importância de uma comunicação válida e capaz de realizar o direito concebido pela própria sociedade e constitucionalmente erigido. Este agir interativo expressa-se na democracia. A ideia de que o direito seria regido pelo princípio da democracia não leva a outra conclusão, senão que a produção de normas é garantida com a participação - e aceitação - popular.

Entender que o direito e a moral se complementam e se regulam, como uma espécie de freios e contrapesos, é necessário para que, como Habermas pontua, seja possível verificar que

\begin{tabular}{ll}
\hline 59 & HABERMAS, 2012. \\
60 & Op. Cit. \\
61 & HABERMAS, 2012, p 221-259
\end{tabular}


“a obrigatoriedade das normas jurídicas remonta não apenas a processo de formação de opinião e vontade, mas sim decisões coletivamente vinculativas, por instâncias que estabelecem e que aplicam o direito"62.

A partir disso é que se perquire a Carta Política: para alcançar legitimidade necessariamente há que passar pelo Poder Social. O consenso obtido desta fórmula é capaz de reconstruir a Carta Política em sua acepção maior, retirando-a do aspecto de constituição de fachada.

Tratando-se de um documento político, a Constituição não pode ser objeto de uso do Estado, posto que, antes, é o instrumento de que se vale a sociedade para sindicar os atos do governo, figurando aqui o ponto nodal da reabilitação política, justamente esta retomada da razão crítica e da ação política eficaz no combate ao exceptio.

\section{A TÍTULO DE CONCLUSÃO}

A Constituição Federal de 1988 é um documento político, com fundamento em princípios de democracia e de Estado de Direito e social. Compreendido o povo como detentor permanente do poder, o exercício desse poder deve ocorrer de forma contínua e constante, não só de tempos em tempos com a escolha de representantes pelo voto. A cultura enquanto elemento constitutivo do Estado Constitucional ${ }^{63}$, serve de apoio para que a sociedade não caia em situação de alienação. Pode-se dizer que a cultura é capaz de dar impulso à Carta Política, que assim como uma flecha, quanto é puxada para trás - revisitando a história e os aspectos pré-constitucionais -, com mais vigor alcança seu objetivo de instrumento de efetivação e concretização do bem-estar de todos, viabilizando-se a realização da equidade e da isonomia.

Os modelos atuais de Estado, de democracia e também - porque não dizer - de indivíduo, reclamam maior deliberação e participação. Não há lugar para a exceção ao direito de conviver, acessar e participar da vida política e das discussões que envolvem o destino de todos.

A medida em que é permitida a entrada dos indivíduos no campo de discussão de ideias e decisões políticas pode ser verificada no nível de democracia de determinado Estado, sociedade ou comunidade e, por consequência lógica, seu afastamento do totalitarismo e da sociedade de controle.

\section{REFERÊNCIAS BIBLIOGRÁFICAS}

ADORNO, Theodor W. 1903-1969. Indústria cultural e sociedade. Seleção de textos Jorge Mattos Brito de Almeida traduzido por Juba Elisabeth Levy [et al.]. — São Paulo Paz e Terra, 2002 .

AGAMBEN, Giorgio. Estado de exceção. Tradução de Iraci D. Poleti. São Paulo: Boitempo, 2004.

$62 \quad$ Op. Cit., p. 290.

63 HABERLE, 2003. 
Homo sacer o poder soberano e a vida nua. Belo Horizonte: UFMG, 2007.

ARENDT, H.A condição humana. Rio de Janeiro : Forense Universitária, 1991.

Sobre a violência. Rio de Janeiro :Relume-Dumará, 1994.

O que é política. Rio de Janeiro : Bertrand Brasil, 1998.

ARISTÓTELES. A Política. São Paulo : Martinez Fontes, 2001.

BAUMAN, Zygmunt. Vigilância Líquida. Rio de Janeiro : Zahar, 2013.

BRASIL. Constituição (1988). Constituição da República Federativa do Brasil: promulgada em 5 de outubro de 1988. Brasília: Senado, 1988.

CANOTILHO, José Joaquim Gomes. Estado de direito. Lisboa: Gradiva Publicações, 1999. CERVANTES, Miguel de. EI cerco de Numancia. Madrid, Ediciones Cátedra, 1999.

COSTA, Nelson Nery. Ciência Política.3 ed. Rio de Janeiro: Forense, 2012.

DeutscherBundestag. Lei Fundamental da República Federal da Alemanha. Tradução publicada pelo Departamento da Imprensa e Informação do Governo da República Federal da Alemanha, 1975.

FACHIN, Zulmar; SAMPAR, Rene. Teoria do Estado. 2 ed. Rio de Janeiro: Lumen Juris, 2017.

FOUCAULT, Michel. História da Sexualidade: a vontade de saber. Vol. 1. Rio de Janeiro : Graal, 1988.

HABERMAS, Jürgen. O conceito de poder em Hannah Arendt. IN : Sociologia. Coleção Grandes Cientistas Sociais. Rio de Janeiro : Ática, 1980.

HABERMAS, Jürgen. A inclusão do outro. Tradução de George Sperber. São Paulo: Edições Loyola, 2002.

. Teoria do agir comunicativo, 2: sobre a crítica da razão funcionalista. Tradução:

Flávio BenoSiebeneichler. São Paulo: Editora WMF Martins Fontes, 2012.

HABERLE, Peter. Hermenêutica Constitucional - A sociedade aberta dos intérpretes da constituição: contribuição para a interpretação pluralista e "procedimental" da constituição. Tradução: Gilmar Ferreira Mendes. Porto Alegre: Sergio Antonio Fabris Editor, 2002.

El Estado Constitucional. México \&Peru :TareaAssociación Gráfica Educativa, 2003.

HARDT, Michael; NEGRI, Antonio. Multidão: guerra e democracia na era do império. São Paulo: Record, 2005.

HESSE, Konrad. A força normativa da constituição.Die normative Kraft der Verfassung. 
Tradução de Gilmar Ferreira Mendes. Porto Alegre: Sergio Antonio Fabris Editor, 1991.

JAKOBS, Günther\& MELIÁ, Manuel Cancio. Direito Penal do Inimigo: noções e críticas. Porto Alegre : Livraria do Advogado, 2005.

JELLINEK, Georg. Teoria General del Estado. México :Fondo de Cultura Económica, 2000.

KANT, I. A paz perpétua e outros opúsculos. Lisboa : Edições 70, 1990.

LA BOÉTIE, Étienne de. Discurso da servidão voluntária ou o contra um. Comentários: Claude Lefort. Pierre Clastres e Marilena Chauí. Tradução: Laymert Garcia dos Santos. São Paulo: Editora Brasiliense, 1999.

MALBERG, R. Carré de. Teoría General del Estado. $2^{\mathrm{a}}$ reimpressão. México :Facultad de Derecho/UNAM : Fondo de Cultura Económica, 2001.

MARTINEZ, Vinício Carrilho. A rede dos cidadãos: a política na Internet. Tese de doutorado. São Paulo : Faculdade de Educação da Universidade de São Paulo (FEUSP), 2001.

Estado de Exceção e Modernidade Tardia: da Dominação Racional à Legitimidade (anti) Democrática. Tese de Doutorado. Programa de Pós-Graduação em Ciências Sociais, UNESP/Marília, 2010.

MARX, Karl. As lutas de classes na França (1848-1850). São Paulo : Global, 1986b.

MIRANDA, Jorge (Org.). Textos Históricos do Direito Constitucional. Lisboa: Imprensa Nacional - Casa da Moeda, 1990.

NIETZSCHE, Friedrich Wilhelm. Além do bem e do mal: prelúdio para uma filosofia do futuro. Jenseits von Gut und Böse. Vorspiel einer Philosophie der Zukunft. Tradução: Márcio Pugliesi. Curitiba: Hemus, 2001.

RADBRUCH, Gustav. Introdução à Ciência do Direito. São Paulo : Martins Fontes, 1999.

SCHERCH, Vinícius A. A legitimidade das decisões políticas: uma análise à luz da democracia deliberativa de Jürgen Habermas. In: XXVI Encontro Nacional do CONPEDI em Brasília - Distrito Federal. Constituição e Democracia I. Florianópolis - SC: CONPEDI, 2017. p. $130-150$.

SUNDFELD, Carlos Ari. Fundamentos de Direito Público. $4^{\mathrm{a}}$ ed, $5^{\mathrm{a}}$ tiragem. Malheiros Editores : São Paulo, 2004.

WEBER, MAX. Ensaios de Sociologia. Rio de Janeiro : Zahar Editores, 1979. Sociologia. $4^{\text {a }}$ ed. São Paulo : Ática, 1989.

Economia e Sociedade: fundamentos da sociologia compreensiva. Vol I e II. BrasíliaDF : Editora Universidade de Brasília : São Paulo : Imprensa Oficial do Estado, 1999. 
Como citar: MARTINEZ, Vinício Carrilho. SCHERCH, Vinívius Alves. A carta política na sociedade de controle. Revista do Instituto de Direito Constitucional e Cidadania, Londrina, v. 3, n. 1, p. 135-154, jan/jun. 2018.

Recebido em: 10/02/2018

Aprovado em: 25/02/2018 